\title{
THE SOLAR EUROPE INDUSTRY INITIATIVE: RESEARCH, TECHNOLOGY DEVELOPMENT AND DEMONSTRATION IN SUPPORT OF 2020 AND LONG-TERM TARGETS
}

\author{
Wim C. Sinke ${ }^{1,2}$, Daniel Fraile Montoro ${ }^{3}$, Eleni Despotou ${ }^{3}$, Stefan Nowak ${ }^{2,4}$ and Emiliano Perezagua ${ }^{2,5}$ \\ ${ }^{1}$ ECN Solar Energy, POB 1, NL-1755 ZG Petten, The Netherlands (address for correspondence) \\ ${ }^{2}$ European Photovoltaic Technology Platform, Brussels, Belgium \\ ${ }^{3}$ European Photovoltaic Industry Association, Brussels, Belgium \\ ${ }^{4}$ NET Nowak Energy \& Technology Ltd., Ursen, Switzerland \\ ${ }^{5} \mathrm{PV}$ Consulting, Madrid, Spain
}

\begin{abstract}
The European Union has set an ambitious target for the implementation of renewable energy technologies by 2020 , i.e. a share of $20 \%$ of the total energy consumption. In support of these targets the Strategic Energy Technology (SET) Plan has been initiated by the European Commission. One of the key components of this plan is the establishment of Industry Initiatives aiming at technology development and demonstration to enable large-scale deployment at minimum cost and maximum benefits for society. The Solar Europe Industry Initiative (SEII), covering both photovoltaic solar energy and concentrating solar power has been launched in June 2010. It provides clear, technology-related targets and priorities for research, development and demonstration, for EU as well as member state programs. The PV-part of the SEII is a joint effort of the European Photovoltaic Technology Platform and the European Photovoltaic Industry Association, which together represent most of the R\&D and industry capacity in Europe.
\end{abstract}

\section{BACKGROUND AND CONTEXT}

The Solar Europe Industry Initiative (SEII) synthesizes a collective effort of the European PV community, involving leading representatives from the industry, from the research community and from the European and national PV associations represented through the European Photovoltaic Industry Association (EPIA) and the European Photovoltaic Technology Platform (EUPVTP).

This paper summarizes the European PV sector strategy and the immediate actions to be taken in the period 20102012 to realize the PV solar energy goals for 2020 and beyond, as described in the European Commission PV Roadmap [1], the EUPVTP's Strategic Research Agenda [2] and its Implementation Plan [3] and related documents, as a contribution to the overall targets of the EU. Implementation of the PV sector strategy is necessary for the European PV industry to remain competitive in a global market where an increasing number of new companies and countries become active and where upscaling of manufacturing and deployment volumes are an essential ingredient of success.

Availability of low-cost, high quality PV technology, wherever it is produced, is a prerequisite for any ambitious deployment scenario. However, the European PV sector has the responsibility and the ambition to maintain a strong position on the global market and to derive economic benefit for the EU taxpayer, who has nursed PV technology through the expensive, initial stages of its development. In response to this situation, and as input for the SET-Plan and EU 2020 targets, the European industry, organized through EPIA, developed a Vision [4] to establish PV as a mainstream clean, sustainable and competitive energy technology providing up to $12 \%$ of the European electricity demand by 2020 , up to $20 \%$ in 2030 and $30 \%$ in 2050 . Realizing this Vision requires that the right policy framework conditions are set by the EU Member States, and that continuous public support is provided to the industry in order to carry out the research, development and demonstration (RD\&D) measures needed. The Solar Europe Industry Initiative describes the strategic RD\&D components of "SET For 2020", which are essential to enable rapid, large-scale deployment of $P V$ at minimum cost and maximum benefit for society. Besides the efforts of the PV sector, the success of other Industry Initiatives under the SET-Plan (e.g. the Electricity Grid Initiative) as well as the development of other technologies (electricity storage, electric vehicles, demand side management, etc.) are essential for the success of the SEII. A $12 \%$ contribution is only possible if costs are substantially reduced (through innovation, experience and economies of volume), grid integration issues can be solved, and PV markets are strongly and sustainably developed throughout Europe. The SEll describes crucial actions to accelerate cost reduction as well as to provide solutions for high penetration of PV in electricity grids and for integration in the built environment, see Figure 1.



Figure 1. Scope of the Solar Europe Industry Initiative. 


\section{STATE OF THE ART AND 2020 OBJECTIVES}

For over 30 years the PV industry has demonstrated its capability to achieve fast price reduction, as evidenced by Figure 2, which shows that the price of PV modules has been reduced by $\approx 20 \%$ for each doubling of the cumulative production. The same is roughly true on the system level (note that PV systems consist of modules and the so-called Balance of System (BoS), which comprises electronics and safety devices, cabling, mounting structures, installation, etc.). The rapid decrease of turn-key system prices has been enabled by the combination of innovation (the result of RD\&D) and experience combined with economies of scale (the result of market development).

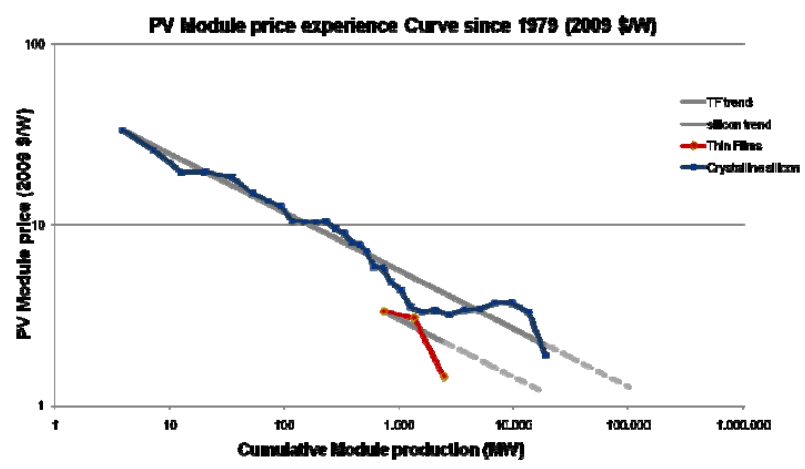

Figure 2. Price-experience curve for photovoltaic modules (courtesy EPIA, 2009).

Clearly, RD\&D (the topic of this SEII) by itself will not lead to large scale deployment and to reaching any volume target. The latter is dependent on important other conditions to be met, in particular in the form of market incentives until self-sustained markets are created by continued cost and price reductions. It is stressed, however, that intensified RD\&D is crucial to enable PV deployment at the rate and at the rapidly decreasing price levels outlined in "SET for 2020". In other words, the SEII enables such large scale deployment at minimum cost and maximum benefit. In fact, the societal cost benefits that may be reached by choosing an optimum combination of deployment ambition and RD\&D efforts easily outweighs the cost of the latter, which is another argument to adopt this SEII.

Although costs and prices of modules and complete systems are important indicators of the evolution of the technology, the most relevant parameter and actually the one which serves to compare PV electricity with other sources of energy is the Levelized Cost of Electricity (LCoE) per kWh generated. Depending on the location, the annual output (proportional to the annual irradiation) varies from $700-800 \mathrm{kWh} / \mathrm{kWp}$ in the Scandinavian countries to more than $1500 \mathrm{kWh} / \mathrm{kWp}$ in the South of Spain and Italy, Greece and Turkey.

Table I summarizes selected performance indicators for past and state-of-the-art PV components and systems in Southern Europe (assuming a system performance ratio of 0.8 ), as well as indicative targets for 2015 and 2020 (please note the Table footnotes).

\begin{tabular}{|c|c|c|c|c|c|}
\hline & & 2007 & 2010 & 2015 & 2020 \\
\hline \multicolumn{2}{|c|}{ Turn-key price larger systems $(€ / \mathrm{Wp})^{*}$} & $\geq 5$ & $2,5-3,5$ & 2 & 1,5 \\
\hline \multicolumn{2}{|c|}{$\begin{array}{l}\text { PV electricity generation cost in Southern EU } \\
\qquad(€ / \mathrm{kWh})^{\star *}\end{array}$} & $0.30-0.60$ & $0.13-0.25$ & $0.10-0.20$ & $0.07-0.14$ \\
\hline \multirow{3}{*}{$\begin{array}{l}\text { Typical PV module } \\
\text { efficiency range (\%) }\end{array}$} & Crystalline silicon & $13-18 \%$ & $15-20 \%$ & $16-21 \%$ & $18-23 \%$ \\
\hline & Thin films & $5-11 \%$ & $6-12 \%$ & $8-14 \%$ & $10-16 \%$ \\
\hline & Concentrators & $20 \%$ & $20-25 \%$ & $25-30 \%$ & $30-35 \%$ \\
\hline \multicolumn{2}{|c|}{ Inverter lifetime (years) } & 10 & 15 & 20 & $>25$ \\
\hline \multicolumn{2}{|c|}{ Module lifetime (years) } & $20-25$ & $20-25$ & $25-30$ & $35-40$ \\
\hline \multicolumn{2}{|c|}{ Energy pay-back time (years) } & $2-3$ & $1-2$ & 1 & 0.5 \\
\hline \multicolumn{2}{|c|}{ 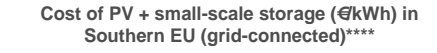 } & - & 0.35 & 0.22 & $<0.15$ \\
\hline \multicolumn{6}{|c|}{  } \\
\hline
\end{tabular}

Table 1. Indicative targets of the Solar Europe Industry Initiative.

\section{SEII STRUCTURE AND PRIORITY AREAS}

The Solar Europe Industry Initiative is based on the idea of "Creating an energy revolution through accelerated evolution" and moving beyond a business-as-usual scenario. Based on an intensive exchange of views and ideas which were worked out in a close collaboration between EPIA and the European Photovoltaic Technology Platform, involving stakeholders from the whole $P V$ industry (cell \& module manufacturers, Balance of System suppliers), the research community (universities, research centers), PV-related industries (glass, plastics \& encapsulants, raw materials, metals) and, last but not least, equipment suppliers, two major initiatives have been defined:

- SEII 1: Cost reduction

- SEII 2: System integration

Following the R\&D activities in the two sub-initiatives, demonstration projects will be carried out to assure a large and successful implementation of the results. The SEII also recognizes the need to develop a program for education \& training in Europe, to enable world-class innovation and to avoid a shortage of qualified PV professionals. Activities should address the specific needs of the industry as well as those of the research and development sector and include scientists, engineers, installers, technicians, etc.. The same principle applies for raising awareness \& communication activities. The 
environmental, social, economical and technical benefits of PV need to be disseminated to the wider public, national and European policy-makers, utilities, architects, construction sector and other important stakeholders. These two areas (i.e. education \& training and raising awareness \& communication), however, are beyond the scope of Industrial Initiatives and should be covered by parallel actions, see Figure 3.



Figure 3. Interaction of the SEII with other initiatives, as well as related actions.

\section{SEII 2: System integration}

As distributed PV and other renewable energy technologies mature, they can provide a significant share of European electricity demand. However, as their market share grows, concerns about potential impacts on the stability and operation of the electricity grid may create barriers to their future expansion. In addition, low cost, high-quality integration of $\mathrm{PV}$ in buildings and other objects poses major development challenges. The goal of this part of the initiative is to unlock the potential for making PV a mainstream energy source, requiring special focus to be placed on system integration aspects. In order to achieve the target of generating up to $12 \%$ of the European electricity consumption by 2020 , the PV industry, together with the network operators and building sector, needs to develop economical and technical solutions which will allow a large penetration of $\mathrm{PV}$ at a competitive level. The implementation of this part of the initiative will bring benefits to the PV industry, utilities and regulators. On one hand, the production cost of components like inverters and batteries will decrease whereas the lifetime of those devices will increase making PV systems more economically attractive. On the other hand, grid operation will benefit from the ancillary services (frequency stability, voltage control, reactive power) that PV can bring into the system, as well as the reliability of supply when offering PV systems with energy storage solutions. Communication and control functionalities will be developed, tested and implemented facilitating the overall function of energy management systems.

\section{Demonstration projects}

The results of the activities implemented under the priority areas "Cost reduction" and "System integration" will be demonstrated under real conditions. The collaboration with other key stakeholders such as utilities, car manufactures and regulators on the one hand and the building industry on the other is also essential at this level. A variety of tests and demonstrations are required to understand the effect of a high penetration of PV systems on the grid. Especially important are the subjects of PV grid integration, PV building integration and interaction with other energy sources (such as wind power and other variable electricity production technologies). The implementation of this part of the initiative will demonstrate the real value of PV technology and electricity, the potential to interact with other energy sources and the added value to network operators and the building sector.

\section{FOCUS OF THE SEII 2010-2012: SELECTED PRIORITY AREAS}

To allow a concrete start of the SEII, a tentative set of priority areas has been defined, based on input provided by the industry and research sectors. Member States as well as the European Union are now encouraged to "adopt" those areas which fit best their own strengths and priorities.

The following tables summarize the priority areas (project clusters) for the two main focus areas of the SEII as well as a component aimed at the period beyond 2020 .

\begin{tabular}{|c|l|}
\hline \multicolumn{2}{|c|}{ Cost reduction: paving the way to 2020 } \\
\hline Research theme & $\begin{array}{l}\text { Summary description and } \\
\text { project clusters }\end{array}$ \\
\hline $\begin{array}{c}\text { Advanced } \\
\text { manufacturing } \\
\text { processes for } \\
\text { cells and } \\
\text { modules }\end{array}$ & $\begin{array}{l}\text { This cluster of projects aims at } \\
\text { bringing a selection of key } \\
\text { commercial technologies (in } \\
\text { particular wafer Si, thin-film Si, } \\
\text { CIGS and concentrator PV) further } \\
\text { towards full maturity, i.e. very }\end{array}$ \\
large-scale production at the \\
required low cost. It will enable the \\
European PV industry to compete \\
successfully in the global market, \\
to reach grid parity with retail prices \\
(or beyond) in most of Europe and \\
to supply the required hardware for \\
multi-gigawatt-scale deployment of \\
PV.
\end{tabular}




\begin{tabular}{|c|l|}
\hline & $\begin{array}{l}\text { systems are other ways to reduce } \\
\text { the generation costs of solar } \\
\text { electricity. This cluster of projects } \\
\text { aims at increased specific energy } \\
\text { output (kWh/Wp-yr) and enhanced } \\
\text { lifetime. In addition, the cluster } \\
\text { includes projects on very high } \\
\text { efficiency approaches beyond } \\
\text { industry capability indicated in the } \\
\text { previous block. }\end{array}$ \\
\hline $\begin{array}{c}\text { Materials } \\
\text { sustainability }\end{array}$ & $\begin{array}{l}\text { To further improve the already } \\
\text { favourable environmental profile of } \\
\text { PV systems, the energy input for } \\
\text { manufacturing and installation } \\
\text { needs to be reduced and } \\
\text { alternatives for some critical (non } \\
\text { earth-abundant or hazardous) } \\
\text { elements and materials need to be } \\
\text { developed. Both aspects are also } \\
\text { clearly related to cost reduction. } \\
\text { Moreover, the implementation of } \\
\text { the end-of-life module collection } \\
\text { and recycling system developed by } \\
\text { the PV CYCLE association is } \\
\text { addressed. } \\
\text { a }\end{array}$ \\
\hline
\end{tabular}

\begin{tabular}{|c|l|}
\hline \multicolumn{2}{|c|}{ Cost reduction: paving the way to 2020 } \\
\hline Research theme & $\begin{array}{l}\text { Summary description and } \\
\text { project clusters }\end{array}$ \\
\hline $\begin{array}{c}\text { Advanced } \\
\text { pronufacturing } \\
\text { cells and } \\
\text { modules }\end{array}$ & $\begin{array}{l}\text { This cluster of projects aims at } \\
\text { bringing a selection of key } \\
\text { commercial technologies (in } \\
\text { particular wafer Si, thin-film Si, } \\
\text { CIGS and concentrator PV) further } \\
\text { towards full maturity, i.e. very } \\
\text { large-scale production at the } \\
\text { required low cost. It will enable the } \\
\text { European PV industry to compete } \\
\text { successfully in the global market, } \\
\text { to reach grid parity with retail prices } \\
\text { (or beyond) in most of Europe and } \\
\text { to supply the required hardware for } \\
\text { multi-gigawatt-scale deployment of } \\
\text { PV. }\end{array}$ \\
\hline
\end{tabular}

\begin{tabular}{|c|c|}
\hline $\begin{array}{l}\text { Performance } \\
\text { enhancement } \\
\text { and lifetime } \\
\text { extension }\end{array}$ & $\begin{array}{l}\text { In addition to the performance } \\
\text { optimization and cost reduction on } \\
\text { cell and module levels mentioned } \\
\text { in the previous cluster, } \\
\text { enhancement of the performance } \\
\text { on a system level and } \\
\text { enhancement of the technical } \\
\text { lifetime of system components and } \\
\text { systems are other ways to reduce } \\
\text { the generation costs of solar electricity. } \\
\text { gener } \\
\text { This cluster of projects aims at } \\
\text { increased specific energy output } \\
\text { (kWh/Wp•yr) and enhanced } \\
\text { lifetime. In addition, the cluster } \\
\text { includes projects on very high } \\
\text { efficiency approaches beyond } \\
\text { industry capability indicated in the } \\
\text { previous block. }\end{array}$ \\
\hline $\begin{array}{c}\text { Materials } \\
\text { development \& } \\
\text { sustainability }\end{array}$ & $\begin{array}{l}\text { To further improve the already } \\
\text { favourable environmental profile of } \\
\text { PV systems, the energy input for } \\
\text { manufacturing and installation } \\
\text { needs to be reduced and } \\
\text { alternatives for some critical (non } \\
\text { earth-abundant or hazardous) } \\
\text { elements and materials need to be } \\
\text { developed. Both aspects are also } \\
\text { clearly related to cost reduction. } \\
\text { Moreover, the implementation of } \\
\text { the end-of-life module collection } \\
\text { and recycling system developed by } \\
\text { the PV CYCLE association is } \\
\text { addressed. }\end{array}$ \\
\hline $\begin{array}{l}\text { Large-scale PV } \\
\text { power plants }\end{array}$ & $\begin{array}{l}\text { Technologies with a high potential } \\
\text { but a limited track record, like } \\
\text { concentrator PV and advanced } \\
\text { thin-film technologies, are } \\
\text { hampered in their application } \\
\text { because risk assessment cannot } \\
\text { be based on field experience. This, } \\
\text { in turn, makes it difficult to reach } \\
\text { the scale required for cost } \\
\text { reduction. This circle may be } \\
\text { broken by the development of a } \\
\text { few very large ( } 20-40 \mathrm{MWp)} \mathrm{PV} \\
\text { power plants aimed at } \\
\text { demonstrating the feasibility and } \\
\text { reliability of the respective } \\
\text { technologies. Analyzing the impact } \\
\text { of such large PV plants on the grid } \\
\text { operability and stability will also } \\
\text { support the establishment and } \\
\text { construction of a very robust } \\
\text { European "smart grid". }\end{array}$ \\
\hline
\end{tabular}




\begin{tabular}{|c|l|}
\hline $\begin{array}{c}\text { Solar resources, } \\
\text { monitoring and } \\
\text { simulation }\end{array}$ & $\begin{array}{l}\text { What can we expect and what do } \\
\text { we actually get? These are two key } \\
\text { questions in relation to large-scale } \\
\text { deployment of PV. Projects in this } \\
\text { cluster aim at creating accurate \& } \\
\text { reliable, readily available, and } \\
\text { practically useful information on all } \\
\text { aspects of PV planning and use, } \\
\text { for various stakeholder groups in } \\
\text { all EU member states. }\end{array}$ \\
\hline
\end{tabular}

\begin{tabular}{|c|c|}
\hline \multicolumn{2}{|c|}{$\begin{array}{l}\text { Preparing for cost and penetration beyond } \\
\qquad 2020 \text { levels }\end{array}$} \\
\hline $\begin{array}{l}\text { Ultra low cost } \\
\text { technologies }\end{array}$ & 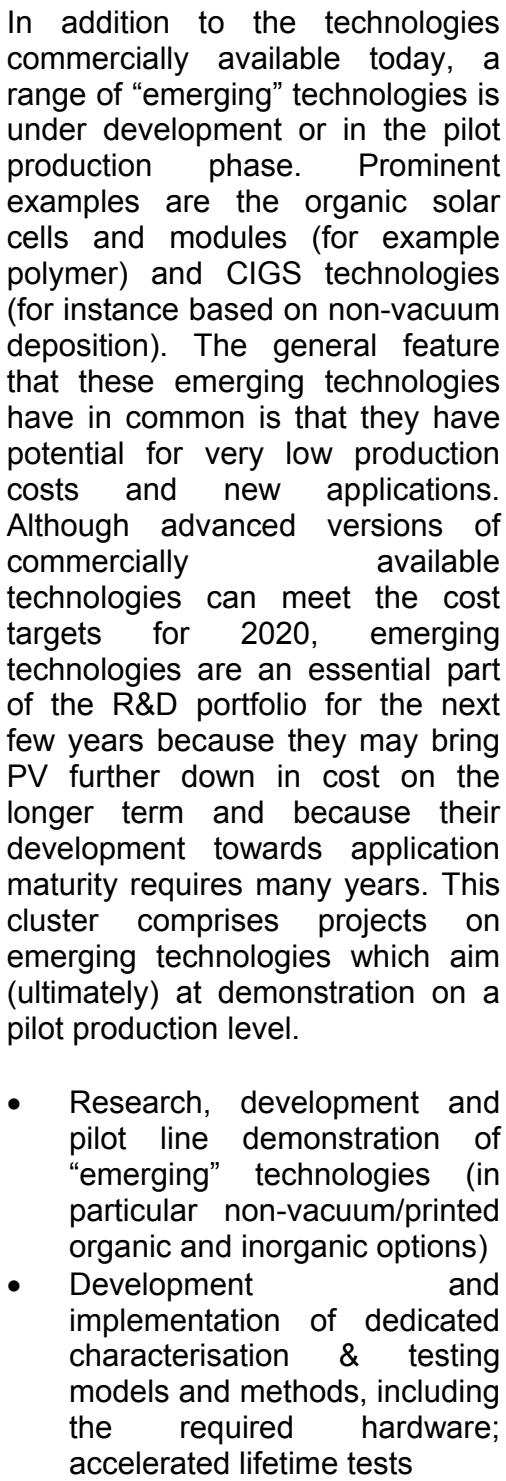 \\
\hline
\end{tabular}

\begin{tabular}{|c|c|}
\hline $\begin{array}{l}\text { Very high } \\
\text { efficiency } \\
\text { approaches }\end{array}$ & $\begin{array}{l}\text { In addition to the commercial and } \\
\text { emerging technologies mentioned } \\
\text { in previous paragraphs, a wide } \\
\text { range of "novel" device and } \\
\text { conversion concepts are in the } \\
\text { laboratory phase. The common } \\
\text { feature of these novel approaches } \\
\text { is that they aim at efficiencies far } \\
\text { beyond the levels foreseen for } \\
\text { commercial and emerging } \\
\text { technologies. Another common } \\
\text { feature is that it is too early to make } \\
\text { useful statements about their } \\
\text { (future) cost. This cluster aims at } \\
\text { exploring the limits of photovoltaic } \\
\text { conversion: a strategic activity } \\
\text { which is vital for the position of the } \\
\text { PV industry sector on the longer } \\
\text { term as well as for Europe's global } \\
\text { position in the PV field. The USA, } \\
\text { Japan, Australia and other } \\
\text { countries invest heavily in similar } \\
\text { R\&D efforts. The aim of the } \\
\text { projects in this cluster is to } \\
\text { demonstrate the feasibility and } \\
\text { added value of the approaches on } \\
\text { a device level. a } \\
\text { - Research and development of } \\
\text { Modelling and characterisation } \\
\text { of new concepts and } \\
\text { innovative materials using } \\
\text { advanced theoretical and } \\
\text { experimental methods } \\
\text { aiming at very high efficiencies } \\
\text { (various applications of } \\
\text { quantum dots and other } \\
\text { nanostructures, intermediate } \\
\text { band semi-conductors, hot- } \\
\text { carrier devices, spectrum } \\
\text { converters, and more); } \\
\text { demonstration on proof-of- } \\
\text { concept and/or proof-of- } \\
\text { feasibility level }\end{array}$ \\
\hline $\begin{array}{c}\text { Integration } \\
\text { concepts for very } \\
\text { high levels of PV } \\
\text { penetration }\end{array}$ & $\begin{array}{l}\text { As in the case of cell and module } \\
\text { technologies, also the concepts } \\
\text { and technologies for integration } \\
\text { have to evolve and improve over } \\
\text { time in order to comply with rapid, } \\
\text { large-scale deployment. To prepare } \\
\text { for very high levels of penetration } \\
\text { of PV in the grid as well as in the } \\
\text { built environment, this project } \\
\text { cluster aims at developing and } \\
\text { demonstrating new integration }\end{array}$ \\
\hline
\end{tabular}




\begin{tabular}{|l|l|}
\hline & $\begin{array}{l}\text { concepts (beyond those developed } \\
\text { in "Grid and building integration"). }\end{array}$ \\
Power and energy \\
management strategies for \\
very high degrees of PV \\
penetration (beyond \\
anticipated 2020 levels), \\
including development and \\
testing of the required \\
hardware, and field tests.
\end{tabular}

To monitor progress of the SEII, a set of Key Performance Indicators (KPI's) has been developed in the framework of SETIS (Strategic Energy Technology Information System). These KPI's relate to reference PV systems and reference PV manufacturing technologies, but also to specific technical parameters on component or system level.

\section{FINANCING}

Although at the start the SEll only has a very limited dedicated budget, it is expected that this will grow over time as existing and new programs are aligned according to the common targets and priorities. The total budget required to carry out the SEII for the period 2010-2020 is estimated to be 9 billion Euros. This amount consists of public (EU and Member States) and private contributions, both in the form of grants and loans, depending on the nature and risk profile of the projects involved. Public contributions vary from less than $30 \%$ to $90 \%$, depending on the project type. On average, for the project clusters that may start in first 3 years of the SEII, the public contribution is approximately $43 \%$. A detailed overview of project clusters and their expected financing is beyond the scope of this paper.

\section{CONCLUSION}

The Solar Europe Industry Initiative has been designed to become the most important vehicle for collaborative PV RD\&D in Europe. It aims to enable PV to make important contributions to the renewable electricity targets for 2020 and beyond and to support the European PV sector to continue to play an important role in manufacturing and deployment of PV technology. The SEII is a joint effort of the majority of EU Member States, the European Commission and the private sector. It has been launched in June 2010 and is expected to grow in volume and scope over the total period of 2010 to 2020 .

\section{REFERENCES}

[1] "A Technology Roadmap for the Communication on Investing in the Development of Low Carbon Technologies (SET-Plan)", Commission Staff Working Document, COM(2009) 519 final (2009), see http://eur-lex.europa.eu.
[2] W.C. Sinke et al., "A Strategic Research Agenda for Photovoltaic Solar Energy Technology", European Photovoltaic Technology Platform, Office for Official Publications of the European Union, Luxembourg (2007), ISBN 978-92-79-05523-2.

[3] W.C. Sinke et al., "Today's actions for tomorrow's PV technology - An implementation Plan for the Strategic Research Agenda of the European Photovoltaic Technology Platform", Office for Official Publications of the European Union, Luxembourg (2009), ISBN 978-92-7912391-7.

[4] SET for 2020: Solar Photovoltaic Electricity - a Mainstream Power Source in Europe by 2020 (Executive Summary), European Photovoltaic Industry Association (2009), see www.setfor2020.eu. 